\title{
Preoperative HE4, CA125 and ROMA in the differential diagnosis of benign and malignant adnexal masses
}

\author{
Katarzyna M. Terlikowska', Bozena Dobrzycka², Anna M. Witkowska', Beata Mackowiak-Matejczyk², \\ Tomasz Kamil Sledziewski ${ }^{2}$, Maciej Kinalski ${ }^{4}$ and Slawomir J. Terlikowski ${ }^{2,5^{*}}$
}

\begin{abstract}
Background: The aim of this study was to evaluate HE4, CA125 and ROMA in the preoperative differentiation benign ovarian diseases from epithelial ovarian cancer depending on the menopausal status.

Methods: In order to estimate markers' concentrations in the serum of women with benign ovarian disease $(n=128)$ and with epithelial ovarian carcinoma $(n=96)$ the electrochemiluminescence $(E C L I A)$ technique has been applied.

Results: Using the ROC analysis, although no statistical differences were found among their AUCs, the ROMA algorithm seems to be effective in gathering the diverse performance of HE4 and CA125. The AUC for HE4, CA125 and ROMA for all patients were: $0.895 ; 0.879$ and 0.918 , respectively. At established new optimal cutoff values for HE4, CA125 and ROMA we found higher specificity in postmenopausal compared to premenopausal women (96.9 vs $89.8 \%$ and 97.7 vs $84.1 \%$ and 95.9 vs $89.1 \%$, respectively). The sensitivity of HE4 in pre- and postmenopausal women was similar (83.5 vs $83.8 \%$ ), while for CA125 was the highest in premenopausal women (87.0 vs $84.1 \%$ ). For HE4, CA125 and ROMA the negative predictive value was high (97.6, 93.9 and $94.4 \%$, respectively).

Conclusions: The ROMA algorithm shows the best diagnostic performance to distinguish epithelial ovarian cancer from benign ovarian disease. We found the high specificity of HE4 and CA125 while differentiating ovarian benign diseases from epithelial ovarian cancer in postmenopausal women and the high sensitivity of CA125 in detecting epithelial ovarian cancer in premenopausal patients.
\end{abstract}

Keywords: HE4, CA125, ROMA, Ovarian cancer

\section{Background}

Ovarian cancer is the most lethal cancer among gynaecological malignancies. In 2012, it was estimated that 238,719 cases were diagnosed and 151,905 women died from this disease worldwide [1]. The estimated number of new ovarian cancer cases in Europe in 2012 was 65,538 with 42,704 deaths [2]. In Poland, ovarian cancer is the second most frequent invasive malignancy of the female genital tract after cancers of the uterine corpus, with an estimated 3,600 cases diagnosed annually. Approximately 2,600 women die each year from ovarian

\footnotetext{
* Correspondence: sterlikowski@gmail.com

${ }^{2}$ Department of Obstetrics, Gynaecology and Maternity Care, Medical University of Bialystok, 15 Warszawska Street, 15-062 Bialystok, Poland ${ }^{5}$ Department of Obstetrics, Gynaecology and Maternity Care, Medical University of Bialystok, Szpitalna 37, 15-295 Bialystok, Poland Full list of author information is available at the end of the article
}

cancer, representing the most common cause of death among women with gynaecological malignancies [3].

Taking into consideration the late stage of diagnosis, our inability to diagnose ovarian cancer at an early stage remains the major problem. Despite the acceptance regarding the influence of reproductive hormones on ovarian cancer risk and considerable advances in the understanding of epithelial ovarian carcinogenesis on a molecular level, there is no complete understanding of the biologic processes underlying malignant transformation of ovarian surface epithelium [4-6]. The contemporary diagnostic standard of ovarian cancer includes transvaginal ultrasound and serum measurement of CA125. However this method has insufficient specificity, especially in women before menopause. A wide range of diagnostic approaches e.g. panels of biomarkers, 
algorithms, ultrasound and other imaging methods are being investigated at present [7, 8]. Among them the usefulness of HE4 in the diagnosis of ovarian cancer has been researched by a few groups [9-13].

Both CA125 and HE4 with menopausal status are currently being incorporated into the Risk of Ovarian Malignancy Algorithm (ROMA) in order to discern malignant from benign pelvic masses. Many studies have demonstrated the clinical utility of serum HE4 and ROMA in women with a complex pelvic mass and may provide even greater accuracy in the risk stratification of epithelial ovarian carcinoma [10, 11, 13, 14].

This study aimed to evaluate HE4, CA125 and ROMA in the preoperative differentiation benign ovarian diseases from epithelial ovarian cancer depending on the menopausal status.

\section{Methods}

The analysis of the preoperative serum concentrations of CA125, HE4 and the ROMA values was performed on the material obtained from the Caucasian women surgically treated from 2012 to 2016 at the Department of Gynaecologic Oncology of the Maria SklodowskaCurie Memorial Bialystok Oncology Centre and at the Department of Gynaecology and Obstetrics of the Jedrzej Sniadecki Memorial Hospital in Bialystok (Poland). It was done on account of benign ovarian disease $(n=128)$ and epithelial ovarian cancer $(n=96)$ according to the international treatment guidelines for ovarian cancer patients, including primary cytoreductive surgery followed by platinum-containing chemotherapy [15].

All surgical specimens were reviewed by 2 dedicated gynaecologic pathologists. Tumours were classified according to the WHO histological criteria [16] and divided into subtypes: serous 59 (61.5\%), mucinous 10 (10.4\%), endometrioid 13 (13.5\%), clear cell 5 (5.2\%), others (mixed non-differentiated) $8(8.3 \%)$ and no data 1 (1.1\%). The samples were grouped by the following histological grades: 5 (5.2 \%) were classified as low-grade (G1), 10 (10.4\%) were medium-grade (G2) and 78 (81.3\%) were in high-grade (G3). Most of the epithelial ovarian cancers were of high grade and were diagnosed at an advanced stage. A total of 24 (25\%) were diagnosed with stage I disease, 11 (11.5\%) with stage II, 48 (50 \%) with stage III and 12 (12.5\%) with stage IV disease, according to the Fédération Internationale de Gynécologie et d'Obstétrique (FIGO) classification criteria [17]. The benign disease group with serous, mucinous, endometriosis, mixed and other cysts of the ovary was also examined histologically. The women were made familiar with procedures and gave their written consent before the study enrolment. The study was approved by the Bioethics Committee of the Medical University of Bialystok (protocol No. R-I-002/68/2012).
Blood samples were collected to Vacutainer sterile tubes (Becton Dickinson, USA) to clot. Samples were then centrifuged for $10 \mathrm{~min}$ at $3000 \mathrm{rpm}$. Recovered sera were pipetted into sterile tubes (Nunc, Denmark) and stored at $-80{ }^{\circ} \mathrm{C}$. Concentrations of HE4 and CA125 were assessed with the electrochemiluminescence (ECLIA) technique on Cobas e411 (Roche Diagnostics, Switzerland) analyser, based on standard protocols. Cutoff levels were 35 $\mathrm{U} / \mathrm{mL}$ for CA125 and $140 \mathrm{pmol} / \mathrm{L}$ for HE4. The range of HE4 and CA125 assays were 15-1500 pmol/l and 0.600$5000 \mathrm{U} / \mathrm{ml}$, respectively. The test precision for both markers was performed in accordance with the protocol guidelines of Clinical and Laboratory Standards Institute (CLSI) [18]. All test runs were duplicated. According to the indications of the manufacturer, an index of ROMA $\geq 11.4$ and $\geq 29.9 \%$ indicates a high risk for the presence of epithelial ovarian cancer in pre- and postmenopausal women, respectively. The patients' clinical status was not known by the people carrying out the assays, and the results of these assays were disclosed to the surgeons only after the patients' disease status was recorded.

\section{Statistical analysis}

ROMA classifies patients as being at a low or at a high risk for malignant disease using the following algorithms:

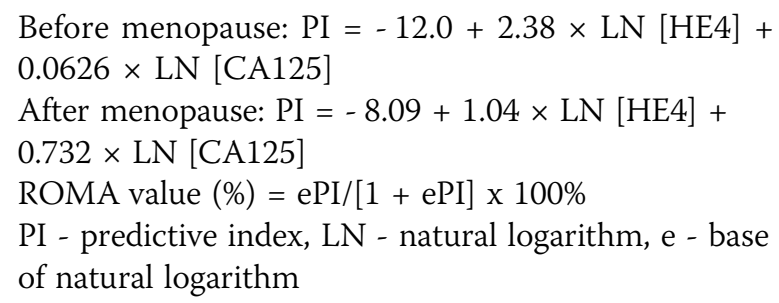

The HE4, CA125 and ROMA median values were compared with the Mann-Whitney $U$ test, and the Kruskal-Wallis one-way analysis of variance by ranks (ANOVA) and the Spearman's rank correlation coefficient (rho). Categorical variables were compared with the Pearson's chi-square test with Yates correction and Fisher's exact test based on the Statistica software package 10.0 PL (StatSoft, Inc. StatSoft Poland Ltd.). Receiver operator characteristic (ROC) curves were constructed, and the area under the curve (ROC-AUC) with a $95 \%$ confidence interval $(95 \% \mathrm{CI})$ was calculated. Sensitivity and specificity were calculated in pre- and postmenopausal women separately and independently of menopausal status. In order to identify patients with cancer, the best cutoff point of CA125, HE4 and ROMA with regard to best values of sensitivity, specificity, positive (PPV) and negative predictive values (NPV) were evaluated. For all statistical comparisons, a $p$ value of $<0.05$ was considered statistically significant. 


\section{Results}

Of the 224 evaluable women, 120 were premenopausal (age: median: 36, range: 25-49) and 104 postmenopausal (age: median: 63, range 53-74 years). The clinical characteristics information of individuals enrolled in our study were shown in Table 1. High serum levels of HE4, CA125 and values of ROMA were found in patients with epithelial ovarian cancer rather than in those with benign diseases $(p<0.001)$. The total median value of HE4, CA125 and ROMA in pre- and postmenopausal women with epithelial ovarian cancer was statistically higher than that in the women with benign diseases $(p<0.001)$. HE4, CA125

Table 1 Clinicopathological characteristics of the patients

\begin{tabular}{|c|c|c|c|}
\hline \multirow[t]{2}{*}{ Pathology } & \multirow[t]{2}{*}{ All patients $n(\%)$} & \multicolumn{2}{|c|}{ Menopausal status } \\
\hline & & Pre- n (\%) & Post- n (\%) \\
\hline Benign ovarian diseases & 128 & 87 & 41 \\
\hline \multicolumn{4}{|l|}{ Histologic type } \\
\hline Serous & $46(35.9)$ & $25(28.7)$ & $21(51.2)$ \\
\hline Mucinous & $13(10.2)$ & $7(8.1)$ & $6(14.6)$ \\
\hline Endometriosis & $33(25.8)$ & $31(35.6)$ & $2(4.9)$ \\
\hline Mixed & $12(9.4)$ & $8(9.2)$ & $4(9.8)$ \\
\hline Other & $24(18.7)$ & $16(18.4)$ & $8(19.5)$ \\
\hline Epithelial ovarian cancer & 96 & 33 & 63 \\
\hline \multicolumn{4}{|l|}{ Histologic type } \\
\hline Serous & $59(61.5)$ & $17(51.4)$ & $42(66.7)$ \\
\hline Endometrioid & $13(13.5)$ & $5(15.2)$ & $8(12.7)$ \\
\hline Mucinous & $10(10.4)$ & $6(18.2)$ & $4(6.3)$ \\
\hline Clear cell & $5(5.2)$ & $3(9.1)$ & $2(3.2)$ \\
\hline Mixed/Undifferentiated & $8(8.3)$ & $2(6.1)$ & $6(9.5)$ \\
\hline No data & $1(1.1)$ & $0(0)$ & $1(1.6)$ \\
\hline \multicolumn{4}{|l|}{ FIGO stage } \\
\hline IA & $5(5.2)$ & $3(9.1)$ & $2(3.2)$ \\
\hline IB & $4(4.1)$ & $2(6.1)$ & $2(3.2)$ \\
\hline IC & 15 (15.6) & $8(24.3)$ & $7(11.1)$ \\
\hline$\| \mathrm{A}$ & $2(2.1)$ & $0(0)$ & $2(3.2)$ \\
\hline$\| \mathrm{B}$ & $1(1.1)$ & $1(3.0)$ & $0(0)$ \\
\hline$\| C$ & $8(8.3)$ & $3(9.1)$ & $5(7.9)$ \\
\hline$\| I I A$ & $3(3.1)$ & $1(3.0)$ & $2(3.2)$ \\
\hline$\| I \mid B$ & $9(9.4)$ & $1(3.0)$ & $8(12.7)$ \\
\hline IIIC & $36(37.5)$ & 11 (33.3) & 25 (39.6) \\
\hline IV & $12(12.5)$ & $2(6.1)$ & $10(15.9)$ \\
\hline not staged & $1(1.1)$ & $1(3.0)$ & $0(0)$ \\
\hline \multicolumn{4}{|l|}{ Grade } \\
\hline G1 & $5(5.2)$ & $3(9.1)$ & $2(3.2)$ \\
\hline G2 & $10(10.4)$ & $6(18.2)$ & $4(6.3)$ \\
\hline G3 & 78 (81.3) & $23(69.7)$ & 55 (87.3) \\
\hline unknown & $3(3.1)$ & $1(3.0)$ & $2(3.2)$ \\
\hline
\end{tabular}

and ROMA values determined in pre- and postmenopausal women with benign diseases and with epithelial ovarian cancer are shown in Table 2.

In the present study we established new cutoff values specific to the examined population for each biomarker, and verified them using ROC analysis to calculate the optimal cutoffs. The best cutoff points distinguishing malignant vs. benign disease for HE4, CA125 and ROMA were 72.3 $\mathrm{pmol} / \mathrm{l} ; 62.2 \mathrm{U} / \mathrm{ml}$ and $20.1 \%$, respectively. Before and after the menopause these values were as follows: 70.3 vs 109.1 pmol/l for HE4; 64.6 vs $39.4 \mathrm{U} / \mathrm{ml}$ for CA125 and 14.9 vs $33.4 \%$ for ROMA. The level of optimal cutoff values for HE4 was lower $(72.3 \mathrm{pmol} / \mathrm{l})$ than the recommended one (140 pmol/l), whereas for CA125 it was higher $(62.2 \mathrm{U} / \mathrm{ml})$ than the suggested one $(35 \mathrm{U} / \mathrm{ml})$, for all patients. The diagnosis accuracy of HE4, CA125 and ROMA was assessed by estimating ROC and AUC for all patients with ovarian cancer versus benign diseases. The AUC values for HE4, CA125 and ROMA were 0.895 (confidence interval (CI) $95 \%, 0.838-0.951$ ), 0.879 (CI $95 \%, 0.818-0.941$ ) and 0.918 (CI $95 \%, 0.853-0.938$ ), respectively. The highest ROCAUC was for ROMA, followed by HE4. When alternative thresholds of $72.3 \mathrm{pmol} / \mathrm{l}$ (all), $70.3 \mathrm{pmol} / \mathrm{l}$ (premenopausal) and $109.1 \mathrm{pmol} / \mathrm{l}$ (postmenopausal) for HE4 were used, the sensitivities of HE4 in detecting epithelial ovarian cancer were enhanced, by $84.1 \%$ (all), $83.5 \%$ (pre-) and $83.8 \%$ (post-), with just a slight loss of specificities from 97.5 to $86.3 \%$ (all) and 98.6 to $89.8 \%$ (pre-), respectively. In postmenopausal women specificity of HE4 rose from 94.2 to 96.9 \%. The PPV for HE4 was $45.2 \%, 46.2$ and 86.8 , respectively. The NPV was $97.6,96.7$ and $89.6 \%$, respectively. While in the case of CA125, the sensitivities obtained by using a modified cutoff value were significantly lower than when using the preferred one in postmenopausal group. The specificities were elevated to $82.4 \%$ (all), $84.1 \%$ (pre-) and $97.7 \%$ (post-). The PPV for CA125 was 41.6, 44.8 and $91.7 \%$ and the NPV was $93.9,94.8$ and $92.8 \%$, respectively. In the analysed groups no clear differences were found for ROMA values between optimal and preferred value settings (Table 3, Fig. 1).

\section{Discussion}

The use of serum markers in a ovarian carcinoma risk classifier is novel but is strongly supported by literature [19]. Since HE4 is overexpressed in ovarian cancers relative to normal tissues, Hellstrom et al. [20] examined the potential of HE4 as a secreted biomarker for ovarian cancer. Studies performed by Bon et al. [21] showed the possibility of using HE4 in ovarian cancer diagnostics. The HE4 serum levels in healthy women have been reported to range from 60 $\mathrm{pmol} / \mathrm{l}$ to $150 \mathrm{pmol} / \mathrm{l}$. The reasons for this wide range might be due to the relationship between increasing HE4 serum levels and increasing age. Women older than 49 years of age have higher concentrations in comparison with 
Table 2 The serum levels of HE4 and CA125 and ROMA values in the examined groups

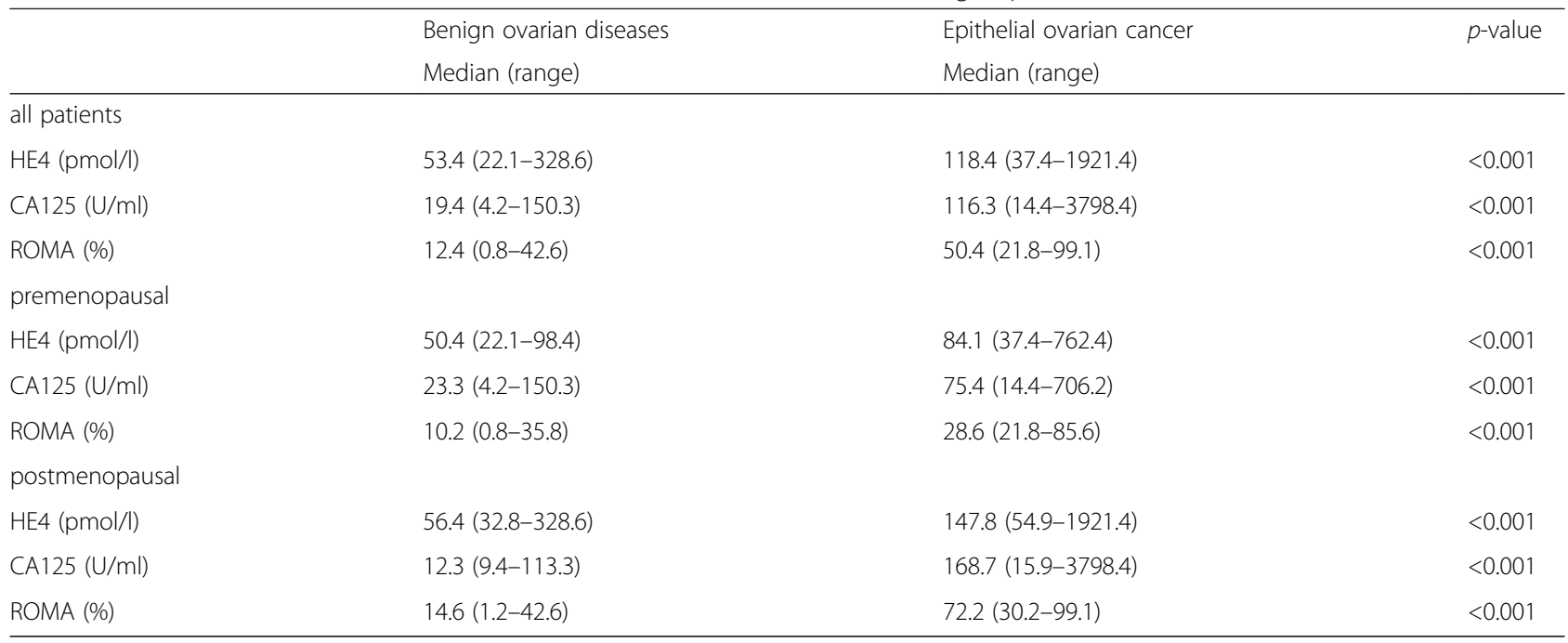

women younger than 40 years. There is a correlation between the histological type and the serum concentration of HE4 with higher concentrations in serous ovarian cancer and with concentrations being lowest in patients with mucinous ovarian carcinomas [22-24].

Postmenopausal women with CA125 concentrations greater than $35 \mathrm{kU} / \mathrm{L}$ should be taken into consideration for transvaginal ultrasound examination as well as a computed tomography scan. The CA125 concentrations greater than $95 \mathrm{kU} / \mathrm{L}$ were reported to discriminate malignant from non-malignant pelvic masses with a positive predictive value of $95 \%$ [25]. For premenopausal women, the American College of Obstetrics and Gynecologists suggested that patients with a pelvic mass and CA125 concentrations greater than $200 \mathrm{kU} / \mathrm{L}$ should be referred to a gynaecologist for consultation $[19,26]$.

In our recent study we showed that in the early stage of endometrioid endometrial cancer, HE4 can serve as a preoperative tool that can help to identify postmenopausal women who may require lymphadenectomy [27]. The present study aimed at evaluating and comparing the role of HE4, CA125 and ROMA value for the differential diagnosis of epithelial ovarian cancer. A cohort of women with benign ovarian diseases was used as the control group. We found that serum concentrations of HE4, CA125 and the ROMA values were significantly elevated in women with epithelial ovarian cancer compared to women with benign disease, both before and after the menopause, being similar to the results from other studies [28]. The data obtained from our study suggests that ROMA algorithm appears to have the best diagnostic performance in distinguishing epithelial ovarian cancer from benign ovarian diseases. Actually, using the ROC analysis while no statistical differences were found among their AUCs, the ROMA algorithm turns out to be effective in recognising the diverse performance of HE4 and CA125. The AUC for HE4, CA125 and ROMA for all patients were: 0.895; 0.879 and 0.918 , respectively. Our results fit the range obtained by other authors: $0.85-0.96 ; 0.81-0.95$ and $0.88-$ $0.97[20,22,29]$. It is worth realising that the ROC

Table 3 Diagnostic accuracy for discriminating between benign ovarian diseases and epithelial ovarian cancer

\begin{tabular}{|c|c|c|c|c|c|c|c|}
\hline $\begin{array}{l}\text { BOD vs } \\
\text { EOC }\end{array}$ & Marker & ROC-AUC (95 \% Cl) & $\begin{array}{l}\text { Cutoff optimal/ } \\
\text { preferred }\end{array}$ & $\begin{array}{l}\text { Sensitivity (\%) } \\
\text { optimal/preferred }\end{array}$ & $\begin{array}{l}\text { Specificity (\%) } \\
\text { optimal/preferred }\end{array}$ & $\begin{array}{l}\text { PPV (\%) } \\
\text { optimal/preferred }\end{array}$ & $\begin{array}{l}\text { NPV (\%) } \\
\text { optimal/preferrec }\end{array}$ \\
\hline \multirow[t]{3}{*}{ all } & HE4 & $0.895(0.838-0.951)$ & $72.3 / 140(\mathrm{pmol} / \mathrm{l})$ & $84.1 / 67.1$ & $86.3 / 97.5$ & $45.2 / 87.4$ & $97.6 / 92.1$ \\
\hline & CA125 & $0.879(0.818-0.941)$ & 62.2 / $35(\mathrm{U} / \mathrm{ml})$ & $83.1 / 81.9$ & 82.4 / 74.1 & $41.6 / 36.9$ & 93.9 / 96.2 \\
\hline & ROMA & $0.918(0.853-0.938)$ & 20.1 / 11.4; $29.9(\%)$ & $86.2 / 84.8$ & $86.8 / 88.2$ & $39.4 / 36.3$ & 94.4 / 96.6 \\
\hline \multirow{3}{*}{$\begin{array}{l}\text { pre- } \\
\text { menopausal }\end{array}$} & HE4 & $0.845(0.806-0.894)$ & $70.3 / 140(\mathrm{pmol} / \mathrm{l})$ & $83.5 / 68.2$ & $89.8 / 98.6$ & $46.2 / 86.4$ & $96.7 / 94.4$ \\
\hline & CA125 & $0.833(0.753-0.944)$ & 64.6 / $35(\mathrm{U} / \mathrm{ml})$ & $87.0 / 86.6$ & $84.1 / 70.9$ & $44.8 / 33.6$ & $94.8 / 96.1$ \\
\hline & ROMA & $0.854(0.778-0.876)$ & 14.9 / $11.4(\%)$ & $86.8 / 86.2$ & $89.1 / 88.8$ & $42.1 / 39.6$ & 97.2 / 98.7 \\
\hline \multirow{3}{*}{$\begin{array}{l}\text { post- } \\
\text { menopausal }\end{array}$} & HE4 & $0.916(0.841-0.979)$ & $109.1 / 140(\mathrm{pmol} / \mathrm{l})$ & $83.8 / 87.1$ & $96.9 / 94.2$ & $86.8 / 92.8$ & $89.6 / 86.2$ \\
\hline & CA125 & $0.904(0.855-0.943)$ & 39.4 / $35(\mathrm{U} / \mathrm{ml})$ & $84.1 / 91.9$ & $96.7 / 89.8$ & $91.7 / 83.2$ & $92.8 / 94.4$ \\
\hline & ROMA & $0.931(0.898-0.959)$ & 33.4 / $29.9(\%)$ & $89.0 / 86.8$ & 95.9 / 92.2 & $91.9 / 89.4$ & $94.2 / 94.9$ \\
\hline
\end{tabular}



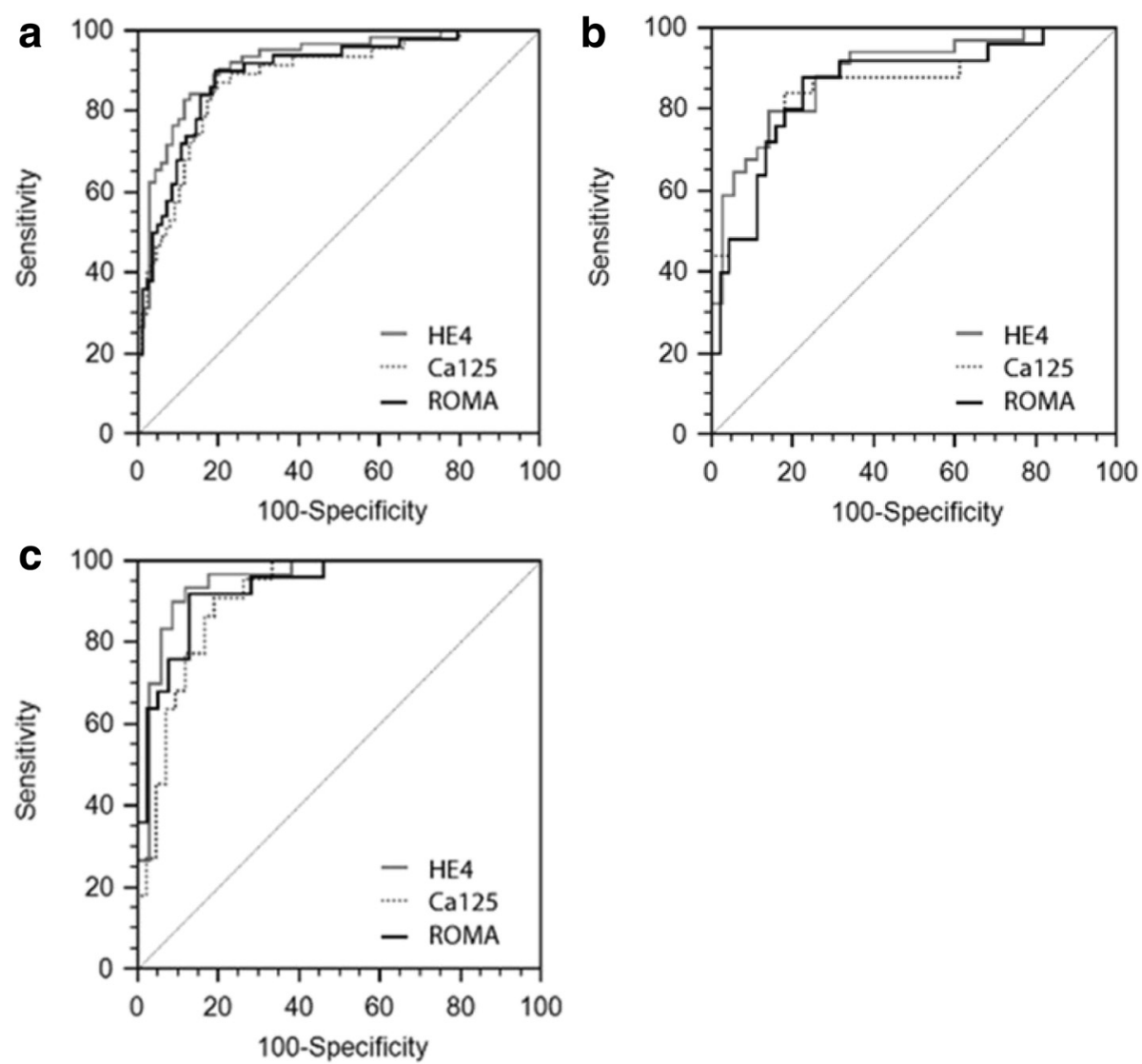

Fig. 1 The ROC curves of HE4, CA125 and ROMA in all patients (a), premenopausal (b) and postmenopausal (c). Area under the ROC curve of HE4, CA125 and ROMA (a): 0.895 vs 0.879 vs 0.918 , (b): 0.845 vs 0.833 vs 0.854 and (c): 0.916 vs 0.904 vs 0.931 , respectively

analysis identifies optimal cutoffs which are different from the recommended routinely used ones for HE4 and CA125, insinuating the possibility of adjusting the cutoff points to the clinical requirements of a given diagnostic setting, as it was formerly reported [30-32]. Therefore, we decided not to use the limits specified by the assay procedures. The values were determined on the basis of the highest accuracy (minimal false negative and false positive results) and cutoffs were calculated depending on the menopausal status. Both in pre- and postmenopausal women, HE4, CA125 and ROMA values acquired similar sensitivity. However, in postmenopausal women all tested markers were characterized by higher specificity. For HE4, CA125 and ROMA the negative predictive value was high. When using the recommended cutoff points indicated by the manufacturers, HE4 yields the best specificity performances in both pre- and postmenopausal patients while CA125 displays the best sensitivity.

Van Gorp et al. [33], supplied insufficient sensitivity of HE4. The cutoff value of HE4 (150 pmol/l) in this study was based on the manufacturer's protocol. HE4 cutoff point of $70 \mathrm{pmol} / \mathrm{l}$ used by Moore et al. [34], achieved $74.5 \%$ of sensitivity and $83.3 \%$ of specificity. Our study showed that the best cutoff point for HE4 was 72.3 pmol/l and depicted $84.1 \%$ of sensitivity and $86.3 \%$ of specificity. The best cutoff values for ROMA in pre- and postmenopausal women, set in the present study, were slightly higher from those suggested by other authors [35, 36]. Moore et al. [34] found higher sensitivity and specificity of ROMA in premenopausal compared to postmenopausal women (92.3 and $75.0 \%$ vs 76.5 and $74.8 \%$, respectively). The cutoff values for ROMA were: 13.1 and $27.7 \%$, respectively. ROMA calculation enabled $93.8 \%$ of ovarian cancer cases to be correctly classified as a high-risk group. For cutoff values suggested by Moore et al. [34] and Bandiera et al. [37] demonstrated $84.6 \%$ of sensitivity and $81.2 \%$ of specificity. Similar results were outlined in a multicentre prospective study from six countries in Asia [38]. In our study, at established new optimal cutoff values for ROMA, we found higher sensitivity and specificity in postmenopausal compared to premenopausal women (89.0 and $95.9 \%$ vs 86.8 and $89.1 \%$, respectively). ROMA also showed significant difference in comparison with HE4 and CA125 for discriminating benign ovarian diseases and epithelial ovarian cancer in all the patients and postmenopausal 
women. The differences between values of sensitivity and specificity probably emerge from variations between the studied groups (different types of epithelial ovarian cancers and the number of investigated cases). Furthermore, our cutoff values were not set at $75 \%$ level of specificity, but we estimated them based on the ROC curve points. Thus, these results need to be confirmed by more well-designed research studies.

\section{Conclusions}

In conclusion, this study confirms the diagnostic role of HE4 and ROMA in epithelial ovarian cancer. The ROMA algorithm appears to show the best diagnostic performance to differentiate epithelial ovarian cancer from benign ovarian disease. We found the high specificity of HE4 and CA125 while discriminating ovarian benign diseases from epithelial ovarian cancer in postmenopausal women and the high sensitivity of CA125 in detecting epithelial ovarian cancer in premenopausal patients. Concisely, our study shows that ROMA algorithm more accurately selects patients with a high risk of ovarian epithelial cancer which enables to direct them to centres specializing in oncological gynaecology.

\section{Abbreviations}

CA125: carbohydrate antigen 125; HE4: human epididymis protein 4; ROMA: Risk of Ovarian Malignancy Algorithm; FIGO: Fédération Internationale de Gynécologie et d'Obstétrique; ECLIA: electrochemiluminescence; CLSI: Clinical and Laboratory Standards Institute; PI: predictive index; LN: natural logarithm; e: base of natural logarithm; ROC: receiver operator characteristic; ROC-AUC: area under the curve; PPV: positive predictive values; NPV: negative predictive values; Cl: confidence interval.

\section{Funding}

The study was supported by grants No. 143-13888P, 143-13890P and 14313891P from Medical University of Bialystok, Poland.

\section{Availability of data and material}

All dataset on which the conclusions are based upon are deposited and presented in the article.

\section{Authors' contributions}

KMT and BD has made substantial contributions to conception and design, planned and ran the experiments, collected data, performed analysis and interpretation of the results, review the literature and wrote the manuscript. TKS, BM-M and MK has contributed in collected data. AMW supervised laboratory diagnostics. SJT have contributed in literature review and given final approval of the version to be published. All authors read and approved the final manuscript.

\section{Competing interests}

The authors declare that they have no competing interests.

\section{Consent for publication}

Not applicable.

\section{Ethics approval and consent to participate}

Ethical permission for the study was approved by the Bioethics Committee of the Medical University of Bialystok (protocol No. R-I-002/68/2012). All patients gave written consent.

\section{Author details}

${ }^{1}$ Department of Food Science and Technology, Medical University of Bialystok, 37 Szpitalna Street, 15-295 Bialystok, Poland. ${ }^{2}$ Department of
Obstetrics, Gynaecology and Maternity Care, Medical University of Bialystok, 15 Warszawska Street, 15-062 Bialystok, Poland. ${ }^{3}$ Department of Gynaecologic Oncology, Maria Sklodowska-Curie Memorial Bialystok Oncology Center, 12 Ogrodowa Street, 15-027 Bialystok, Poland. ${ }^{4}$ Department of Gynaecology and Obstetrics, Jedrzej Sniadecki Memorial Hospital, 15 Warszawska Street, 15-062 Bialystok, Poland. ${ }^{5}$ Department of Obstetrics, Gynaecology and Maternity Care, Medical University of Bialystok, Szpitalna 37, 15-295 Bialystok, Poland.

Received: 23 May 2016 Accepted: 14 July 2016

Published online: 19 July 2016

\section{References}

1. Ferlay J, Soerjomataram I, Ervik M, Dikshit R, Eser S, Mathers C, Rebelo M, Parkin DM, Forman D, Bray F. GLOBOCAN 2012 v1.0, Cancer Incidence and Mortality Worldwide: IARC CancerBase No. 11 [Internet]. International Agency for Research on Cancer: Lyon, France; 2013. Available from: http:// globocan.iarc.fr, accessed on 21 March 2016.

2. Ferlay J, Steliarova-Foucher E, Lortet-Tieulent J, Rosso S, Coebergh JW, Comber H, Forman D, Bray F. Cancer incidence and mortality patterns in Europe: estimates for 40 countries in 2012. Eur J Cancer. 2013:49(6):1374-403.

3. Reports based on data of National Cancer Registry. The Maria SklodowskaCurie Memorial Cancer Center. Department of Epidemiology and Cancer Prevetion, National Cancer Registry 2013. Available from: http://epid.coi. waw.pl/krn, accessed on 23 March 2016.

4. Gharwan $\mathrm{H}$, Bunch KP, Annunziata CM. The role of reproductive hormones in epithelial ovarian carcinogenesis. Endocr Relat Cancer. 2015:22(6):R339_ 63. doi:10.1530/ERC-14-0550.

5. Dobrzycka B, Kinalski M, Piechocka D, Terlikowski SJ. The role of estrogens in angiogenesis in the female reproductive system. Endokrynol Pol. 2009;60(3):210-4.

6. Dobrzycka B, Terlikowski SJ, Kowalczuk O, Niklińska W, Chyczewski L, Kulikowski M. Mutations in the KRAS gene in ovarian tumors. Folia Histochem Cytobiol. 2009;47(2):221-4.

7. Dobrzycka B, Mackowiak-Matejczyk B, Terlikowska KM, Kulesza-Bronczyk B, Kinalski M, Terlikowski SJ. Prognostic significance of pretreatment VEGF, survivin, and Smac/DIABLO serum levels in patients with serous ovarian carcinoma. Tumour Biol. 2015;36(6):4157-65.

8. Dobrzycka B, Mackowiak-Matejczyk B, Terlikowska KM, Kulesza-Bronczyk B, Kinalski M, Terlikowski SJ. Serum levels of IL-6, IL-8 and CRP as prognostic factors in epithelial ovarian cancer. Eur Cytokine Netw. 2013;24(3):106-13.

9. Będkowska GE, Ławicki S, Gacuta E, Pawłowski P, Szmitkowski M. M-CSF in a new biomarker panel with HE4 and CA 125 in the diagnostics of epithelial ovarian cancer patients. J Ovarian Res. 2015;8:27.

10. Granato T, Porpora MG, Longo F, Angeloni A, Manganaro L, Anastasi E. HE4 in the differential diagnosis of ovarian masses. Clin Chim Acta. 2015;446:147-55.

11. Macedo AC, da Rosa MI, Lumertz S, Medeiros LR. Accuracy of serum human epididymis protein 4 in ovarian cancer diagnosis: a systematic review and meta-analysis. Int J Gynecol Cancer. 2014;24(7):1222-31.

12. Lin JY, Qin JB, Li XY, Dong P, Yin BD. Diagnostic value of human epididymis protein 4 compared with mesothelin for ovarian cancer: a systematic review and meta-analysis. Asian Pac J Cancer Prev. 2012;13(11):5427-32.

13. Wu L, Dai ZY, Qian YH, Shi Y, Liu FJ, Yang C. Diagnostic value of serum human epididymis protein 4 (HE4) in ovarian carcinoma: a systematic review and meta-analysis. Int J Gynecol Cancer. 2012;22(7):1106-12.

14. Chudecka-Głaz AM. ROMA, an algorithm for ovarian cancer. Clin Chim Acta. 2014;440C:143-51

15. Benedet $J$, Bender $H$, Jones $H$, Ngan HY, Pecorelli S. FIGO staging classifications and clinical practice guidelines in the management of gynecologic cancers FIGO Committee on Gynecologic Oncology. Int Gynecol Obstet. 2000;70:209-62.

16. Lee KR, Russell P, Tavassoli FA, Buckley CH, Prat J, Pisani P, Dietel M, Schwartz P, Gersell DJ, Goldgar DE, Karseladze Al, Silva E, Hauptmann S, Caduff R, Rutgers J, Kubik-Huch RA. Tumours of the ovary and peritoneum. In: Tavassoli FA, Devilee P, editors. World Health Organization classification of tumours. Lyon: IARC Press; 2003. p. 113-202.

17. Aebi S, Castiglione M, ESMO Guidelines Working Group. Newly and relapsed epithelial ovarian carcinoma: ESMO clinical recommendations for diagnosis, treatment and follow-up. Ann Oncol. 2009;20 Suppl 4:21-3.

18. Garrett PE, Lasky FD, Meier KL. User protocol for evaluation of qualitative test performance: Approved quideline-Second edition. CLSI EP121-A2 2008. Available from: http://www.clsi.org, accessed on 11 February 2016. 
19. Sölétormos G, Duffy MJ, Othman Abu Hassan S, Verheijen RH, Tholander $B$, Bast Jr RC, Gaarenstroom KN, Sturgeon CM, Bonfrer JM, Petersen PH, Troonen H, CarloTorre G, Kanty Kulpa J, Tuxen MK, Molina R. Clinical Use of Cancer Biomarkers in Epithelial Ovarian Cancer: Updated Guidelines From the European Group on Tumor Markers. Int J Gynecol Cancer. 2016;26(1):43-51.

20. Hellström I, Raycraft J, Hayden-Ledbetter M, Ledbetter JA, Schummer M, McIntosh M, Drescher C, Urban N, Hellström KE. The HE4 (WFDC2) protein is a biomarker for ovarian carcinoma. Cancer Res. 2003;63(13):3695-700.

21. Bon GG, Kenemans P, Verstraeten R, van Kamp GJ, Hilgers J. Serum tumor marker immunoassays in gynecologic oncology: establishment of reference values. Am J Obstet Gynecol. 1996;174(1 Pt 1):107-14.

22. Molina R, Escudero JM, Augé JM, Filella X, Foj L, Torné A, Lejarcegui J, Pahisa J. HE4 a novel tumour marker for ovarian cancer: comparison with CA 125 and ROMA algorithm in patients with gynaecological diseases. Tumour Biol. 2011:32(6):1087-95.

23. Zheng $\mathrm{H}$, Gao Y. Serum HE4 as a useful biomarker in discriminating ovarian cancer from benign pelvic disease. Int J Gynecol Cancer. 2012;22(6):1000-5.

24. Escudero JM, Auge JM, Filella X, Torne A, Pahisa J, Molina R. Comparison of serum human epididymis protein 4 with cancer antigen 125 as a tumor marker in patients with malignant and nonmalignant diseases. Clin Chem. 2011:57(11):1534-44.

25. Sturgeon CM, Duffy MJ, Stenman UH, Lilja H, Brünner N, Chan DW, Babaian R, Bast Jr RC, Dowell B, Esteva FJ, Haglund C, Harbeck N, Hayes DF, HoltenAndersen M, Klee GG, Lamerz R, Looijenga LH, Molina R, Nielsen HJ, Rittenhouse H, Semjonow A, Shih IM, Sibley P, Sölétormos G, Stephan C, Sokoll L, Hoffman BR, Diamandis EP, National Academy of Clinical Biochemistry. National Academy of Clinical Biochemistry laboratory medicine practice guidelines for use of tumor markers in testicular, prostate, colorectal, breast, and ovarian cancers. Clin Chem. 2008;54(12):e11-79. doi: 10.1373/clinchem.2008.105601.

26. Committee ACOG. on Gynecologic Practice. The role of the generalist obstetrician-gynecologist in the early detection of ovarian cancer. Int $J$ Gynaecol Obstet. 2003;80:235-8.

27. Dobrzycka B, Mackowiak-Matejczyk B, Terlikowska KM, Kinalski M, Terlikowski SJ. Utility of HE4 to identify patients with endometrioid endometrial cancer who may require lymphadenectomy. Adv Med Sci. 2015;61(1):23-7.

28. Moore RG, Jabre-Raughley M, Brown AK, Robison KM, Miller MC, Allard WJ, Kurman RJ, Bast RC, Skates SJ. Comparison of a novel multiple marker assay vs the Risk of Malignancy Index for the prediction of epithelial ovarian cancer in patients with a pelvic mass. Am J Obstet Gynecol. 2010;203(3):228.e1-6.

29. Ferraro S, Braga F, Lanzoni M, Boracchi P, Biganzoli EM, Panteghini M. Serum human epididymis protein 4 vs carbohydrate antigen 125 for ovarian cancer diagnosis: a systematic review. J Clin Pathol. 2013;66(4):273-81.

30. Moore RG, McMeekin DS, Brown AK, Disilvestro P, Miller MC, Allard WJ, Gajewski W, Kurman R, Bast Jr RC, Skates SJ. A novel multiple marker bioassay utilizing HE4 and CA125 for the prediction of ovarian cancer in patients with a pelvic mass. Gynecol Oncol. 2009;112(1):40-6.

31. Moore RG, Miller MC, Disilvestro P, Landrum LM, Gajewski W, Ball JJ, Skates SJ. Evaluation of the diagnostic accuracy of the risk of ovarian malignancy algorithm in women with a pelvic mass. Obstet Gynecol. 2011;118(2 Pt 1):280-8.

32. Cho HY, Park SH, Park YH, Kim HB, Kang JB, Hong SH, Kyung MS. Comparison of HE4, CA125, and Risk of Ovarian Malignancy Algorithm in the Prediction of Ovarian Cancer in Korean Women. J Korean Med Sci. 2015:30(12):1777-83.

33. Van Gorp T, Cadron I, Despierre E, Daemen A, Leunen K, Amant F, Timmerman D, De Moor B, Vergote I. HE4 and CA125 as a diagnostic test in ovarian cancer: prospective validation of the Risk of Ovarian Malignancy Algorithm. Br J Cancer. 2011;104(5):863-70.

34. Moore RG, Brown AK, Miller MC, Skates S, Allard WJ, Verch T, Steinhoff M, Messerlian G, DiSilvestro P, Granai CO, Bast Jr RC. The use of multiple novel tumor biomarkers for the detection of ovarian carcinoma in patients with a pelvic mass. Gynecol Oncol. 2008;108(2):402-8

35. Lenhard M, Stieber P, Hertlein L, Kirschenhofer A, Fürst S, Mayr D, Nagel D, Hofmann K, Krocker K, Burges A. The diagnostic accuracy of two human epididymis protein 4 (HE4) testing systems in combination with CA125 in the differential diagnosis of ovarian masses. Clin Chem Lab Med. 2011;49(12):2081-8.

36. Ruggeri G, Bandiera E, Zanotti L, Belloli S, Ravaggi A, Romani C, Bignotti E, Tassi RA, Tognon G, Galli C, Caimi L, Pecorelli S. HE4 and epithelial ovarian cancer: comparison and clinical evaluation of two immunoassays and a combination algorithm. Clin Chim Acta. 2011;412(15-16):1447-53.

37. Bandiera E, Romani C, Specchia C, Zanotti L, Galli C, Ruggeri G, Tognon G, Bignotti E, Tassi RA, Odicino F, Caimi L, Sartori E, Santin AD, Pecorelli S, Ravaggi
A. Serum human epididymis protein 4 and risk for ovarian malignancy algorithm as new diagnostic and prognostic tools for epithelial ovarian cancer management. Cancer Epidemiol Biomarkers Prev. 2011;20(12):2496-506.

38. Chan KK, Chen CA, Nam JH, Ochiai K, Wilailak S, Choon AT, Sabaratnam S, Hebbar S, Sickan J, Schodin BA, Sumpaico WW. The use of HE4 in the prediction of ovarian cancer in Asian women with a pelvic mass. Gynecol Oncol. 2013;128(2):239-44

\section{Submit your next manuscript to BioMed Central and we will help you at every step:}

- We accept pre-submission inquiries

- Our selector tool helps you to find the most relevant journal

- We provide round the clock customer support

- Convenient online submission

- Thorough peer review

- Inclusion in PubMed and all major indexing services

- Maximum visibility for your research

Submit your manuscript at www.biomedcentral.com/submit
Ciomed Central 